\title{
ОКРЕМІ АСПЕКТИ РЕАЛІЗАЦІЇ ПРАВ, СВОБОД ТА ОБОВ'ЯЗКІВ ВНУТРІШНЬО ПЕРЕМІЩЕНИХ ОСІБ В УКРАЇНI
}

Грохольський В. Л., Швець Л. В.

Стаття присвячена досить важливій проблемі - дослідженню питань з реалізації прав, свобод та обов'язків внутрішньо переміщених осіб.

У статmі проаналізовано норми Закону України «Про забезпечення прав і свобод внутрішньо переміщених осіб» та з'ясовано перелік і зміст таких прав, свобод і обов'язків.

Проаналізовано Порядок створення, ведення mа доступу до відомостей ЄӘиної інформаційної бази даних про внутрішньо переміщених осіб, який затверджено постановою Кабінету Міністрів України від 22.09.2016 № 646.

Звернута увага на необхідність вирішення таких питань, як: оформлення спадкування майна та отримання свідоцтва про право на спадщину у разі, коли відомості внесені до Реєстру спадкових справ ще до початку військових дій, але спадкові справи залишилися на тимчасово окупованій території; визнання дійсними раніше посвідчених заповітів; отримання свідоцтва про право на спадщину у зв'язку з відмовою нотаріусів у їх видачі через відсутність можливості надати довідку з місия проживання померлого щодо зареєстрованих у житловому приміщенні осіб або неможливістю провести оцінку нерухомого майна, яке перебуває на тимчасово непідконтрольній територіі; проблеми доступу до правосуддя, а саме відсутність установ, які надають послуги у сфері юстиції та правосуддя на непідконтрольних уряду територіях, та ін.

Наголошено, що в Україні на законодавчому рівні визначено права, свободи і обов'язки внутрішньо переміщених осіб, але їх реалізація потребує створення певного адміністративно-правового механізму, який би забезпечував процес як самої реалізації прав, свобод і обов'язків внутрішньо переміщених осіб, так і надавав би змогу оперативно реагувати на нові виклики з регулювання та реалізації таких питань. $\epsilon$ ще велика кількість проблем, які досі залишаються неврегульованими.

Визначено, що лише через створення дієвої системи нормативно-правових актів внутрішньо переміщені особи матимуть можливість реалізувати свої права та належним чином виконувати обов'язки.

Ключові слова: внутрішньо переміщені особи, права, свободи, обов'язки внутрішньо переміщених осіб, ЄӘина інформаційна база даних внутрішньо переміщених осіб.
Hrokholskyi V. L., Shvets L. V. Some aspects of the realization of the rights, freedoms and responsibilities of internally displaced persons in Ukraine

The article is devoted to a very important issue the study of the implementation of the rights, freedoms and responsibilities of internally displaced persons. The article analyzes the provisions of the Law of Ukraine "On Ensuring the Rights and Freedoms of Internally Displaced Persons" and clarifies the list and content of such rights, freedoms and responsibilities.

The Procedure for creating, maintaining and accessing information to the Unified Information Database on Internally Displaced Persons, which was approved by the Resolution of the Cabinet of Ministers of Ukraine of September 22, 2016 No. 646.

Attention was drawn to the need to address such issues as: registration of inheritance of property and obtaining a certificate of inheritance in the case when the information is entered in the Register of Inheritance before the hostilities, but inheritance remained in the temporarily occupied territory; recognition of previously certified wills as valid; obtaining a certificate of inheritance in connection with the refusal of notaries to issue them due to the inability to provide a certificate of residence of the deceased in respect of persons registered in the dwelling or the inability to assess real estate located in temporarily uncontrolled territory; problems of access to justice, namely, the lack of institutions that provide services in the field of justice and justice in areas not controlled by the government, etc.

It is emphasized that the rights, freedoms and responsibilities of internally displaced persons are defined at the legislative level in Ukraine, but their implementation requires the creation of a certain administrative and legal mechanism that would ensure the process of realization of rights, freedoms and responsibilities of internally displaced persons and would enable a rapid response to new challenges in regulating and implementing such issues. There are still a large number of problems that still remain unresolved. It is determined that only through the creation of an effective system of regulations, internally displaced persons will be able to exercise their rights and perform their duties properly.

Key words: internally displaced persons, rights, freedoms, responsibilities of internally displaced persons, Unified Information Database of Internally Displaced Persons.

( Г Грохольський В. Л., Швець Л. В., 2020 
Постановка проблеми та іï актуальність. Ситуація, яка склалася у 2014 році в Україні, а саме анексія АР Крим, збройна агресія на Сході країни, зумовила виникнення проблеми вимушеного переміщення всередині країни. Велика маса людей змінила своє місце проживання, переміщуючись усередині країни. Тому перед державою гостро постало питання визначення правового статусу цих осіб та порядку реалізації ними прав, свобод та обов'язків.

В умовах збройних конфліктів, навіть у разі втрати контролю над частиною власної території, зобов'язання держави щодо захисту прав людини не зникають. Ефективний захист внутрішньо переміщених осіб залежить від держави, у якій такі особи перебувають. Тому основним завданням держави $\epsilon$ визначення на законодавчому рівні механізму реалізації прав, свобод та виконання обов'язків внутрішньо переміщеними особами (далі - ВПО).

Аналіз останніх досліджень і публікацій. Слід відзначити, що окремі питання адміністративно-правового статусу внутрішньо переміщених осіб знайшли своє відображення у наукових працях вітчизняних науковців, зокрема: К.О. Крахмальова, Л.М. Ніколенко, В.І. Михайловського, І.С. Басова, І.Г. Козинець, О.А. Малиновської, В.В. Тимчак, П.А. Трачук, М.В. Кобець, М.А. Бояринцева, О.А. Фесенко, Т.А. Плугатар, Т.О. Подоляки та ін. Але, незважаючи на наявність наукових праць, які не завжди охоплюють увесь спектр наявних проблем, досі $\epsilon$ багато питань, які потребують адміністративно-правового вирішення, а саме реалізації прав, свобод та обов'язків внутрішньо переміщених осіб.

Метою статті $\epsilon$ дослідження окремих аспектів реалізації прав, свобод та обов'язків внутрішньо переміщених осіб у сучасних умовах.

Виклад основного матеріалу. Відповідно до ст. 1 Закону України «Про забезпечення прав і свобод внутрішньо переміщених осіб» (далі - Закон) внутрішньо переміщеною особою $\epsilon$ громадянин України, іноземець або особа без громадянства, яка перебуває на території України на законних підставах та має право на постійне проживання в Україні, яку змусили залишити або покинути своє місце проживання у результаті або з метою уникнення негативних наслідків збройного конфлікту, тимчасової окупації, повсюдних проявів насильства, порушень прав людини та надзвичайних ситуацій природного чи техногенного характеру [1].

Станом на 1 лютого 2021 року, за даними $\epsilon_{\text {ди- }}$ ної інформаційної бази даних про внутрішньо переміщених осіб (далі - ВПО), взято на облік 1459462 переселенці з тимчасово окупованих територій Донецької та Луганської областей та АР Крим [2].

У ст. 2 Закону визначається, що Україна вживає всіх можливих заходів, передбачених Конституцією та законами України, міжнародними договорами, згода на обов'язковість яких надана Верховною Радою України, щодо запобігання виникненню передумов вимушеного внутрішнього переміщення осіб, захисту та дотримання прав і свобод внутрішньо переміщених осіб, створення умов для добровільного повернення таких осіб до покинутого місця проживання або інтеграції за новим місцем проживання в Україні [1].

Закон передбачає, що факт внутрішнього переміщення підтверджується довідкою про взяття на облік внутрішньо переміщеної особи, що діє безстроково.

Для отримання довідки про взяття на облік внутрішньо переміщеної особи така особа звертається із заявою до структурного підрозділу з питань соціального захисту населення районних, районних у місті Києві державних адміністрацій, виконавчих органів міських, районних у містах (у разі утворення) рад за місцем проживання у порядку, встановленому Кабінетом Міністрів України. Вказані органи розглядають заяву i у встановлений законом строк приймають рішення про видачу довідки про взяття на облік чи про відмову у ії видачі.

3 метою обліку внутрішньо переміщених осіб

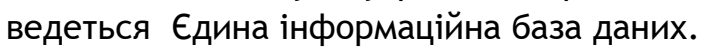

Відповідно до Порядку створення, ведення та доступу до відомостей Єдиної інформаційної бази даних про внутрішньо переміщених осіб база даних - автоматизований банк відомостей, створений для забезпечення єдиного державного обліку фізичних осіб, які $\epsilon$ внутрішньо переміщеними. Відповідальним за забезпечення формування та ведення бази даних $\epsilon$ Мінсоцполітики. Персональні дані в базі даних зберігаються протягом десяти років після закінчення дії обставин, які стали причиною набуття статусу внутрішньо переміщеної особи [3].

Законом України «Про забезпечення прав і свободвнутрішньо переміщених осіб»уч. 1 ст. 9визначається перелік прав, свобод та обов'язків внутрішньо переміщених осіб, а саме:

- право на реєстрацію місця проживання внутрішньо переміщеної особи;

- право на отримання документів, що посвідчують особу та підтверджують громадянство 
України, або документів, що посвідчують особу та підтверджують її спеціальний статус;

- право зареєстрованих внутрішньо переміщених осіб на зайнятість, пенсійне забезпечення, загальнообов'язкове державне соціальне страхування, соціальні послуги, освіту;

- виборче право;

- інші права внутрішньо переміщеної особи та їі обов'язки: єдність родини; сприяння органами державної виконавчої влади, органами місцевого самоврядування та суб'єктами приватного права у пошуку та возз'єднанні членів сімей, які втратили зв'язок внаслідок внутрішнього переміщення; інформацію про долю та місцезнаходження зниклих членів сім'ї та близьких родичів; безпечні умови життя і здоров'я; достовірну інформацію про наявність загрози для життя та здоров'я на території іï покинутого місця проживання, а також місця іï тимчасового поселення, стану інфраструктури, довкілля, забезпечення ії прав і свобод; створення належних умов для іï постійного чи тимчасового проживання; оплату вартості комунальних послуг, електричної та теплової енергії, природного газу в місцях компактного поселення внутрішньо переміщених осіб (містечках із збірних модулів, гуртожитках, оздоровчих таборах, будинках відпочинку, санаторіях, пансіонатах, готелях тощо) за відповідними тарифами, встановленими на такі послуги та товари для населення; забезпечення органами державної виконавчої влади, органами місцевого самоврядування та суб'єктами приватного права можливості безоплатного тимчасового проживання (за умови оплати особою вартості комунальних послуг) протягом шести місяців з моменту взяття на облік внутрішньо переміщеної особи; для багатодітних сімей, осіб з інвалідністю, осіб похилого віку цей термін може бути продовжено; сприяння у переміщенні ії рухомого майна; сприяння у поверненні на попереднє місце проживання; забезпечення лікарськими засобами у випадках та порядку, визначених законодавством; надання необхідної медичної допомоги в державних та комунальних закладах охорони здоров'я; влаштування дітей у дошкільні та загальноосвітні навчальні заклади; отримання соціальних та адміністративних послуг за місцем перебування; проведення державної реєстрації актів цивільного стану, внесення змін до актових записів цивільного стану, їх поновлення та анулювання за місцем перебування; безкоштовний проїзд для добровільного повернення до свого покинутого постійного місця проживання у всіх видах громадського транспорту у разі зник- нення обставин, що спричинили таке переміщення; отримання гуманітарної та благодійної допомоги [1].

Крім прав, ч. 2 ст. 9 Закону визначається перелік обов' язків внутрішньо переміщених осіб:

1) дотримання Конституції та законів України, інших актів законодавства;

2) повідомлення про зміну місця проживання структурного підрозділу з питань соціального захисту населення районних, районних у місті Києві державних адміністрацій, виконавчих органів міських, районних у містах (у разі утворення) рад за новим місцем проживання протягом 10 днів з дня прибуття до нового місця проживання.

У разі добровільного повернення до покинутого постійного місця проживання внутрішньо переміщена особа зобов'язана повідомити про це структурний підрозділ з питань соціального захисту населення районних, районних у місті Києві державних адміністрацій, виконавчих органів міських, районних у містах (у разі утворення) рад за місцем отримання довідки не пізніш як за три дні до дня від'їзду;

3) у разі виявлення подання внутрішньо переміщеною особою завідомо неправдивих відомостей для отримання довідки про взяття на облік відшкодувати фактичні витрати, понесені за рахунок державного та місцевих бюджетів у результаті реалізації прав, передбачених Законом.

Внутрішньо переміщена особа зобов'язана виконувати інші обов'язки, визначені Конституцією та законами України [1].

Незважаючи на визначення прав і свобод внутрішньо переміщених осіб на законодавчому рівні, дієвість цих норм $€$ малоефективною, незаперечним $\epsilon$ факт, що ВПо стикаються з проблемами реалізації своїх прав, свобод та виконання певних обов'язків.

Слід погодитися з Л.М. Ніколенко, що серед проблем, з якими зіткнулися ВПО, неможливо визначити, які $\epsilon$ основними або першочерговими та потребують негайного вирішення, а які - додатковими або малозначними. Усі вони стосуються людського життя, прав та інтересів громадян, що залишили місця свого постійного проживання. Стосовно захисту соціальних прав ВПО автор зазначає, що він залишається на низькому рівні [4].

Питання захисту соціальних прав ВПО потребують визначення механізму для здійснення пенсійних та соціальних виплат особам, які проживають як на контрольованій урядом території, так i на тимчасово непідконтрольних територіях. Також залишається невирішеним питання стосовно 
поновлення виплати пенсій громадянам України, які від початку збройного конфлікту перемістилися та проживають на території інших держав. Додаткового захисту потребують права ВПО стосовно працевлаштування в контексті наявного в деяких регіонах дискримінаційного ставлення місцевого населення до переселенців. Проблема виникає через те, що ВПО сприймають як тимчасових працівників. У регіонах, із яких виїхали ВПО, зосереджені великі промислові об'єкти, на яких і працювала більшість громадян. Тому таким особам важко знайти роботу за професією через відсутність аналогічних об'єктів в інших регіонах країни. Особливої уваги з боку законодавця потребують жінки, які виховують малолітніх дітей і позбавлені можливості працювати повний робочий день, та пенсіонери. Такій категорії осіб узагалі неможливо знайти роботу. Тому держава повинна законодавчо визначити гарантії щодо забезпечення роботою зазначених осіб [4].

Виникають також проблеми щодо спадкування майна. Для внутрішньо переміщених осіб діє загальний порядок спадкування. Але наявні певні особливості щодо місця відкриття спадщини та подання документів для вступу у спадщину у разі, якщо останнім місцем проживання спадкодавця був населений пункт, на території якого органи державної влади тимчасово не здійснюють або здійснюють не в повному обсязі свої повноваження.

Відповідно до ст. 1221 цК України місцем відкриття спадщини $є$ останнє місце проживання спадкодавця. Якщо місце проживання спадкодавця невідоме, місцем відкриття спадщини є місцезнаходження нерухомого майна або основної його частини, а за відсутності нерухомого майна - місцезнаходження основної частини рухомого майна. В особливих випадках місце відкриття спадщини встановлюється законом [5].

Серед низки проблем забезпечення прав і свобод ВПО нині є: неможливість отримати свідоцтво про право на спадщину у разі, коли відомості внесено до Реєстру спадкових справ ще до початку військових дій, але спадкові справи залишилися на тимчасово окупованій території; визнання дійсними раніше посвідчених заповітів; неможливість отримати свідоцтво про право на спадщину у зв'язку з відмовою нотаріусів у їх видачі через відсутність можливості надати довідку з місця проживання померлого щодо зареєстрованих у житловому приміщенні осіб або неможливістю провести оцінку нерухомого майна, яке перебуває на тимчасово непідконтрольній території [6].
Наявні й інші проблеми, зокрема, проблеми доступу до правосуддя, а саме відсутність установ, які надають послуги у сфері юстиції та правосуддя, на непідконтрольних уряду територіях. Захоплення приміщень судів і прокуратур озброєними групами, пов'язаними 3 «ДНР» i «ЛНР», i конфіскація матеріалів справ призвели до неможливості державних установ функціонувати у цьому регіоні. Внаслідок того, що на непідконтрольних територіях Уряд припинив діяльність усіх установ, що надають послуги у сфері юстиції та правосуддя, зокрема, такі базові послуги, як нотаріальне посвідчення документів і видача свідоцтв про народження або смерть, паралельні «системи правосуддя» «ДНР» $\mathrm{i}$ «ННР залишились єдиними «постачальниками юридичних послуг». Однак ці системи не дотримуються українського законодавства, мають обмежене фінансування та недостатню кількість фахівців; вони здебільшого непрозорі та функціонують у надзвичайно складних умовах. Відсутність будь-яких державних установ у поєднанні з недоліками паралельних «систем правосуддя» призводить до неможливості населення на територіях, підконтрольних «ДНР» i «ЛНР», реалізувати свої основні права. 3 огляду на те, що діяльність усіх урядових установ на непідконтрольних уряду територіях було припинено, доступ до української системи правосуддя для населення можливий тільки на підконтрольній уряду території. До того ж після припинення діяльності урядових установ було ухвалено низку законодавчих актів з метою врегулювання ситуації в окремих районах Донецької та Луганської областей. Однак ці законодавчі акти також ускладнюють доступ до послуг у сфері юстиції та правосуддя для населення непідконтрольних уряду територій. Так, наприклад, згідно з наказом Міністерства юстиції України було тимчасово припинено доступ нотаріусів до державних реєстрів на непідконтрольних уряду територіях Луганської та Донецької областей, визначених Міністерством юстиції, до завершення Антитерористичної операції [7].

Висновки. Незважаючи на те, що в Україні на законодавчому рівні визначено права, свободи і обов'язки ВПО, їх реалізація ще потребує створення певного адміністративно-правового механізму, який би забезпечував як саму реалізацію прав, свобод і обов'язків ВПо, так і оперативно реагував би на нові виклики з регулювання та реалізації прав, свобод та обов'язків внутрішньо переміщених осіб. Нині у цьому напрямі $\epsilon$ ще велика кількість проблем, які досі залишаються неврегульованими. Немає єдиного підходу до вирішення низки питань реалізації прав, сво- 
бод та обов'язків внутрішньо переміщених осіб, зокрема щодо належної реалізації житлових прав ВПо, компенсацій за пошкоджене (зруйноване) майно, оформлення пенсійних виплат громадян, які раніше працювали на тимчасово окупованій території, оформлення спадщини, доступ до правосуддя тощо. Тому попереду ще $\epsilon$ значна кількість проблем, які потрібно вирішити на рівні держави. Внутрішньо переміщені особи - це населення України, яке потребує захисту і підтримки з боку держави.

\section{Література}

1. Про забезпечення прав і свобод внутрішньо переміщених осіб : Закон України від 20.10.2014 № 1706-VII. URL: https://zakon.rada.gov.ua (дата звернення: 10.02.2021).

2. Урядовий портал. Єдиний вебпортал органів виконавчої влади. URL: https:// www.kmu.gov.ua/news/oblikovano-1-459-462-vnutrishnoperemishcheni-osobi (дата звернення: 25.02.2021).

3. Про затвердження Порядку створення, ведення та доступу до відомостей Єдиної інформаційної бази даних про внутрішньо переміщених осіб : Постанова Кабінету Міністрів України від 22.09.2016 № 646. URL: https: / / zakon.rada.gov.ua/laws/show/646-2016-\%D0\%BF\#n8 (дата звернення: 25.02.2021).

4. Ніколенко Л.М. Забезпечення реалізації та захисту прав внутрішньо переміщених осіб. Право- вий часопис Донбасу. 2020. № 3 (72). С. 47-54. URL: https: / /doi.org/10.32366/2523-4269-2020-72-3-47-54 (дата звернення: 26.02.2021).

5. Цивільний кодекс : Закон України від 16.01.2003 № 435-IV. URL: https://zakon.rada. gov.ua/laws/show/435-15\#Text (дата звернення: 26.02.2021).

6. Захист прав внутрішньо переміщених осіб: аналіз та рекомендації щодо вдосконалення нормативно-правової бази (станом на 1 березня 2018 року). Київ. 2018. URL: https://www.vplyv.org.ua/ wp-content/uploads/2018/06/Group-of-Influence analyses.pdf (дата звернення: 26.02.2021).

7. Тематичний звіт. Доступ до правосуддя в контексті конфлікту в Україні. Грудень 2015. Спеціальна моніторингова місія ОБСЄ в Україні 2015. URL: https://www.osce.org/files/f/documents/e/f/ 212321.pdf (дата звернення: 26.02.2021).

Грохольський В. Л., доктор юридичних наук, професор, перший проректор Одеського державного університету внутрішніх справ

Швець Л. В., аспірант кафедри кібербезпеки та інформаційного забезпечення одеського державного університету внутрішніх справ 